\title{
Apatinib for advanced sarcoma: results from multiple institutions' off-label use in China
}

\author{
Lu Xie ${ }^{1}$, Wei Guo ${ }^{1 *} \mathbb{D}$, Ye Wang ${ }^{2}$, Taiqiang Yan ${ }^{3}$, Tao Ji ${ }^{1}$ and Jie Xu
}

\begin{abstract}
Background: Anti-angiogenesis Tyrosine kinase inhibitors (TKIs) have been proved to show promising effects on prolonging progression-free survival (PFS) for advanced sarcoma after failure of standard multimodal Therapy. Methylsulfonic apatinib is one of those TKIs which specifically inhibits VEGFR-2. This paper summarizes the experience of three Peking University affiliated hospitals in off-label use of apatinib in the treatment of extensively pre-treated sarcoma.

Methods: We retrospectively analysed files of patients with advanced sarcoma not amenable to curative treatment, who were receiving an apatinib-containing regimen between June 1, 2015 and December 1, 2016. Fifty-six patients were included: 22 osteosarcoma, 10 Ewing's sarcoma, 3 chondrosarcoma and 21 soft tissue sarcoma.

Results: With median follow-up time of 6 months (range, $0.7-18.0 \mathrm{~m}$ ), thirty-five (62.5\%) patients had partial response, and disease was stable in 11 (19.6\%). The 4-month and 6-month progression-free survival rates were 46.3 and 36.5\%, respectively. The median duration of response was 3.8 months $(95 \% \mathrm{Cl} 1.9-5.6 \mathrm{~m})$, with much variability among disease subtypes. The median overall survival was 9.9 months (95\% Cl 7.6-12.2 m). Grade 3 and 4 toxicities were observed in 8 (14.3\%) patients, the most common being hypertension, pneumothorax, wound-healing problems, anorexia, and rash or desquamation.

Conclusions: Apatinib might be effective, with a high objective response rate, in an off-label study of sarcoma patients with advanced, previously treated disease. The duration of response was consistent with reports in different subtypes of sarcomas. Prospective trials of apatinib in the treatment of selected subtypes of sarcomas are needed.

Trial registration: Retrospectively registered in the Medical Ethics Committee of Peking University People's Hospital, Peking University Shougang Hospital and Peking University International Hospital. The trial registration number is 2017PHB176-03 and the date of registration is January 20th 2017.
\end{abstract}

Keywords: Apatinib, Tyrosine-kinase inhibitor, Osteosarcoma, Chondrosarcoma, Soft-tissue sarcoma, Ewing sarcoma

\section{Background}

Sarcomas are a rare, heterogeneous family of mesenchymal tumors, consisting mostly of bone tumors and soft tissue sarcoma (STS) [1, 2]. Use of traditional chemotherapeutic treatments has been limited by poor response rates in patients with relapsed or advanced disease. Nowadays more and more attention are paid to anti-angiogenesis tyrosine kinase inhibitors (TKIs), especially in the field of advanced osteosarcoma and soft tissue sarcoma. However, no or little progress has been

\footnotetext{
* Correspondence: bonetumor@163.com

'Peking University People's Hospital, Peking, China

Full list of author information is available at the end of the article
}

made in treatment of these tumors since Grignani et al. [3] reported landmark phase II cohort trials of sorafenib or sorafenib combined with everolimus [4] in advanced refractory osteosarcoma.. PALETTE study proved that pazopanib could obviously prolong the progression-free survival (PFS) by 3 months but the partial response rate was only $6 \%$. [5]

China has many patients with advanced sarcoma who need to be treated and managed properly. However, the country lacks resources necessary for participation in large multi-center trials. Thus, based on the results of prospective trials abroad, patients with advanced and refractory metastatic disease here are often treated with apatinib off- 
label, which is also an anti-angiogenesis TKIs domestically made and highly selectively inhibitor on VEGFR-2.. The $\mathrm{IC}_{50}$ of apatinib is $2 \mathrm{nM}$ for VEGFR-2, $70 \mathrm{nM}$ for VEGFR$1,420 \mathrm{nM}$ for c-kit and $537 \mathrm{nM}$ for PDGFR- $\beta[6,7]$.

This report aims to describe objectively the use, efficacy, and safety of apatinib in advanced sarcoma patients who have been previously treated in the orthopedic oncology departments of three affiliated hospitals of Peking University,in China: Peking University People's Hospital, Peking University Shougang Hospital, and Peking University International Hospital. A determination will be made whether apatinib warrants further investigations for sarcoma patients.

\section{Methods}

From June 1st 2015 to December 1st 2016, patients who met the following criteria were included: 1) histologically confirmed high-grade sarcoma; 2) initial treatment in the orthopedic oncology departments of the three affiliated hospitals of Peking University; 3) tumors not amenable to curative treatment or inclusion in clinical trials; 4) unresectable local advanced lesions or multiple metastatic lesions that could not be cured by local therapy; 5) measurable lesions according to Response Evaluation Criteria for Solid Tumors (RECIST1.1) [8]; 6) Eastern Cooperative Oncology Group performance status 0 or 1 [9]; and 7) acceptable hematologic, hepatic, and renal function.

All patients or children's legal parent had ever signed informed consent for data collection and use for research purpose. The study was approved by the Institutional Review Board of Peking University People's Hospital, Peking University Shougang Hospital, and Peking University International Hospital Ethics Committee for Clinical Investigation.

Because of various characteristics of diseases, we usually gave patients the following treatment before apatinib. Osteosarcoma patients usually progressed through four drugs, including doxorubicin, cisplatin, high-dose methotrexate, ifosfamide Ewing's sarcoma patients usually progressed through at least two lines of chemotherapy, including VDC-IE (vincristine, doxorubicin, cyclophosphamide sequenced with ifosfamide and etoposide) and VTI (vincristine, temozolomide, irinotecan). For soft tissue sarcoma, patients usually progressed through at least doxorubicin and ifosfamide. But sometimes apatinib together with $\mathrm{GT}$, which was gemcitabine $1000 \mathrm{mg} / \mathrm{m}^{2} \mathrm{~d}_{1,8}$ and docetaxel $75 \mathrm{mg} / \mathrm{m}^{2} \mathrm{~d}_{8}$ once every 21 day, were given to some initial ASPS and epithelioid sarcoma patients because of their poor response to conventional chemotherapy (Tables 1 and 3).

In the phase I trial, apatinib (Jiangsu Hengrui Medicine, Lianyungang, China) had good oral bioavailability at a dose of $850 \mathrm{mg}$ a day, the maximum-tolerated dose [10]. Our patients were mostly given $750 \mathrm{mg}$ apatinib orally once daily for body surface area $(B S A)>1.5$, and $500 \mathrm{mg}$ daily for $\mathrm{BSA}<1.5$. If the patient was less than 10 years of age, we usually used $250 \mathrm{mg}$ directly. If treatment interruptions occurred because of grade 3 hematologic or grade 2 non-hematologic toxicities, doses were reduced, and supportive care was given for the management of adverse events (AEs).

The primary objective of this study was to summarize our experience on the efficacy of off-label use of apatinib in sarcoma patients. Our main concern was the objective response rate $(C R+P R)$ and progression-free-survival (PFS) for each protocol as described containing apatinib according to RECIST 1.1. Together with that, overall survival (OS), duration of response (DR) and the characterization of toxicities were also described. In our retrospective study, PFS was defined as time from the start of using apatinib until disease progression or death, whichever occurred first. The time from appearance of response or stable disease to progression or death was thus considered the DR.

PFS and OS were estimated by use of the Kaplan Meier method, with 95\% confidence interval (CI), and comparisons were made with a log-rank test in the IBM SPSS 22.0 software. Safety evaluation was based on the frequency and severity of toxicities, graded according to the Common Terminology Criteria for Adverse Events [11]. Quantitative variables and categorical variables were analyzed with Cox univariate analysis. All statistical analyses were two-sided, and significance was set at $P<$ 0.05 or at the $95 \% \mathrm{CI}$ for the results of statistical tests. The database was locked for statistical analysis in January 2017, and this is a descriptive analysis.

\section{Results}

\section{Patients' characteristics}

From June 1st 2015 to December 1st 2016, 63 consecutive advanced sarcoma patients were registered. Median followup time was 6.0 months (range, $0.7-18.0 \mathrm{~m}$ ). Five patients were lost to follow up; 1 patient stopped using apatinib because of toxicity and another dropped out for another reason. Finally, 56 patients were enrolled: 22 osteosarcoma, 10 Ewing's sarcoma, 6 synovial sarcoma, 3 malignant peripheral nerve sheath tumors (MPNST), 2 epithelioid sarcoma, 4 undifferentiated pleomorphic sarcoma (UPS), 1 fibrosarcoma, 3 chondrosarcoma, 3 alveolar soft part sarcoma (ASPS), 1 extraskeletal osteosarcoma, and 1 mucinoustype liposarcoma (Table 1). Seventeen (30.3\%) of the sarcomas originated primarily from the axial skeleton; 37 (66. 1\%) from extremities; 2 (3.5\%) were soft tissue sarcomas originated from the mediastinum or back side. Forty (71. 4\%) patients had only multiple pulmonary metastasis; 3 (5. 4\%) had only multiple bone lesions; 5 (8.9\%) had metastasis of both lung and bone; and 5 (8.9\%) had metastases to other sites. Table 1 illustrates that none of the 
Table 1 population characteristics

\begin{tabular}{|c|c|c|c|}
\hline Characteristics & $\begin{array}{l}\text { Number of } \\
\text { patients }\end{array}$ & $\begin{array}{l}\text { Percentage } \\
\& \text { range }\end{array}$ & $\begin{array}{l}P \text { (Cox analysis } \\
\text { for PFS) }\end{array}$ \\
\hline Gender & 56 & $100 \%$ & 0.050 \\
\hline Male & 33 & $58.9 \%$ & \\
\hline Female & 23 & $41.1 \%$ & \\
\hline Age at diagnosis & & & 0.982 \\
\hline $\begin{array}{l}\text { Median (min-max) } \\
\text { (year) }\end{array}$ & 24.5 & $9-63$ & \\
\hline Pathological diagnosis & 56 & $100 \%$ & 0.087 \\
\hline Osteosarcoma & 22 & $39.3 \%$ & \\
\hline Ewing sarcoma & 10 & $17.9 \%$ & \\
\hline Synovial sarcoma & 6 & $10.7 \%$ & \\
\hline MPNST $^{a}$ & 3 & $5.4 \%$ & \\
\hline Epithelioid sarcoma & 2 & $3.6 \%$ & \\
\hline $\mathrm{UPS}^{\mathrm{b}}$ & 4 & $7.1 \%$ & \\
\hline Fibrosarcoma & 1 & $1.8 \%$ & \\
\hline Chondrosarcoma & 3 & $5.4 \%$ & \\
\hline ASPS $^{c}$ & 3 & $5.4 \%$ & \\
\hline Others $^{d}$ & 2 & $3.6 \%$ & \\
\hline \multicolumn{4}{|l|}{ Tumor grade } \\
\hline Grade III & 56 & $100 \%$ & \\
\hline $\begin{array}{l}\text { Location of primary } \\
\text { disease }\end{array}$ & 56 & $100 \%$ & 0.374 \\
\hline Axial skeleton & 17 & $30.3 \%$ & \\
\hline Extremities & 37 & $66.1 \%$ & \\
\hline Others ${ }^{\mathrm{e}}$ & 2 & $3.6 \%$ & \\
\hline Localization of relapse & 56 & $100 \%$ & 0.541 \\
\hline Localized & 3 & $5.6 \%$ & \\
\hline Metastatic & 41 & $73.2 \%$ & \\
\hline Both & 12 & $21.4 \%$ & \\
\hline Type of metastasis & 53 & $94.6 \%$ & 0.197 \\
\hline Lung only & 40 & $71.4 \%$ & \\
\hline Bone only & 3 & $5.4 \%$ & \\
\hline Both & 5 & $8.9 \%$ & \\
\hline Other ${ }^{\mathrm{e}}$ & 5 & $8.9 \%$ & \\
\hline \multicolumn{3}{|c|}{$\begin{array}{l}\text { Time interval from initial chemotherapy } \\
\text { to using apatinib }\end{array}$} & 0.584 \\
\hline $\begin{array}{l}\text { Median (min-max) } \\
\text { (month) }\end{array}$ & 15.6 & $0.9-373.9$ & \\
\hline $\begin{array}{l}\text { Number of previous } \\
\text { treatment lines }\end{array}$ & 56 & $100 \%$ & 0.231 \\
\hline 0 & 5 & $8.9 \%$ & \\
\hline 1 & 37 & $66.1 \%$ & \\
\hline 2 & 12 & $21.4 \%$ & \\
\hline$>2$ & 2 & $3.6 \%$ & \\
\hline
\end{tabular}

Table 1 population characteristics (Continued)

\begin{tabular}{llll}
\hline Characteristics & $\begin{array}{l}\text { Number of } \\
\text { patients }\end{array}$ & $\begin{array}{l}\text { Percentage } \\
\text { \& range }\end{array}$ & $\begin{array}{l}P \text { (Cox analysis } \\
\text { for PFS) }\end{array}$ \\
\hline $\begin{array}{l}\text { Follow-up time } \\
\begin{array}{l}\text { Median (min-max) } \\
\text { (month) }\end{array}\end{array}$ & 6.0 & $0.7-18.0$ & \\
\hline
\end{tabular}

${ }^{a}$ MPNST: malignant peripheral nerve sheath tumor

bUPS: undifferentiated pleomorphic sarcoma

'ASPS: alveolar soft part sarcoma

${ }^{d}$ others including extraskeletal osteosarcoma one case and mucinous type liposarcoma one case

eothers including mediastinum and soft tissue of the backside

fothers including lymph nodes metastasis or intravenous tumor emboli as well as liver, brain metastasis

clinicopathological factors examined (gender, age, pathological subtypes, location of primary disease, localization of relapse, type of metastasis, time interval from initial chemotherapy to starting using apatinib, number of previous treatment lines) had an evident influence on progression-free survival (PFS) $(P \geq .05)$.

Before treatment with apatinib, a median of 1.5 lines of chemotherapy (range 1-4) was administrated. Five (8. 9\%) patients received no chemotherapy before using target therapy, 3 of whom had ASPS and 2 had epithelioid sarcoma. Thirty-seven (66.1\%) patients (mostly osteosarcoma) had progressed through 1 line of chemotherapy before using apatinib, while 14 (25\%) had been through 2 or more than 2 lines of chemotherapy (Table 1).

\section{Treatment protocols}

Forty-four of the $56(78.6 \%)$ patients received only apatinib (oral administration); 7 (12.5\%) received apatinib and everolimus in combination; and $5(8.9 \%)$ received apatinib with gemcitabine and docetaxel (Table 2).

Most of our patients were conventionally evaluated by their doctors at clinic every 2 months with at least chest $\mathrm{CT}$ and imaging of tumor lesions at other sites. If some of them could not go to clinic because of poor health status, our medical secretaries would call the patients for updates. However at last information collection, 5 patients were lost to follow-up (we usually defined as no information update for at least three months). Eventually we reviewed all their radiographs and pathological materials for this study.

Table 2 Different treatment combination and median duration of response

\begin{tabular}{llll}
\hline Target therapy & $\begin{array}{l}\text { Patient } \\
\text { number (N) }\end{array}$ & Best response $^{\text {a }}$ & $\begin{array}{l}\text { Median (average) } \\
\text { DR (months) }\end{array}$ \\
\hline Apatinib alone & $44(78.6 \%)$ & PR & $3.8(5.4)$ \\
Apatinib+everolimus & $7(12.5 \%)$ & PR & $8.5(7.3)$ \\
Apatinib+GT & $5(8.9 \%)$ & PR & $8.5(7.3)$ \\
\hline
\end{tabular}

${ }^{\mathrm{a}} P R$ partial response, $S D$ stable disease according to RECIST 1.1

${ }^{b} G T$ chemo-protocol combined with gemcitabine $1000 \mathrm{mg} / \mathrm{m}^{2} \mathrm{~d}_{1,8}$ and docetaxel $75 \mathrm{mg} / \mathrm{m}^{2} \mathrm{~d}_{8}$ once every 21 days 


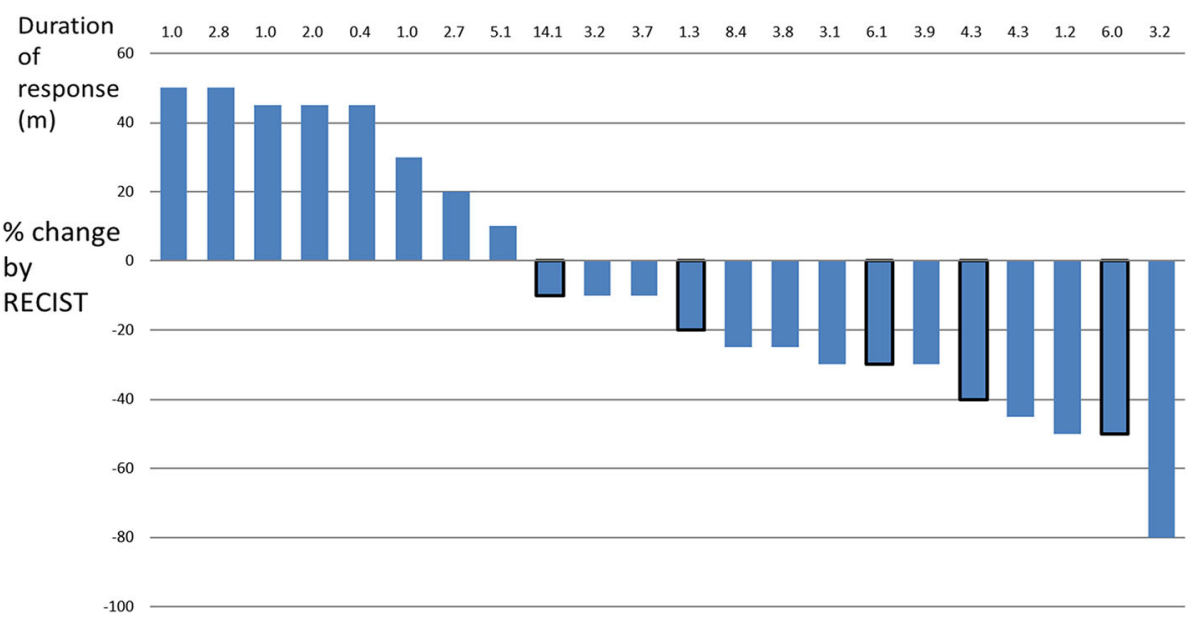

Fig. 1 Waterfall plot of best change from baseline for 22 osteosarcoma patients. Patients' clinical evaluations are indicated on the vertical graph as total volume increase or decrease. The numbers on the horizontal graph indicate the number of months of duration response. Strips with black frame indicate follow-up not yet at end point, and the patients' status might continue unchanged for some while

\section{Efficacy of apatinib-included therapies}

As of the most recent follow up, 35 (62.5\%) patients had partial responses and 11 (19.6\%) had stable disease (Fig. 1). The 4-month and 6-month PFS rates were 46.3 and 36.5\%, respectively. The median duration of response (DR) was 3 . 8 months (95\% CI,; 1.9-5.6 m; which varied among pathological subtypes: $3.1 \mathrm{~m}(95 \% \mathrm{CI}$; $2.7-4.1 \mathrm{~m})$ for osteosarcoma, $2.0 \mathrm{~m}$ (95\% CI; 1.3-2.7 m) for Ewing's sarcoma, 5. $2 \mathrm{~m}$ (95\% CI; 0.9-9.5 m) for synovial sarcoma, $8.8 \mathrm{~m}$ (95\% CI; $4.3-11.5 \mathrm{~m}$ ) for MPNST, and $5.6 \mathrm{~m}$ (95\% CI, 1.3-9. $8 \mathrm{~m}$ ) for UPS (Table 3).

The response conditions are illustrated in in Figs. 1, 2 and 3 . The objective response rate $(C R+P R$ according to RECIST 1.1) was $40.9 \%$ (9/22) for osteosarcoma, $70 \%$ (7/10) for Ewing's sarcoma, 100\% (3/3 cases) for chondrosarcoma, and 71.4\% (15/21) for soft tissue sarcoma.

\section{Toxicity and safety}

Treatment was interrupted in 10/56 (18.0\%) cases because of disease progression. A 16-year-old female osteosarcoma patient died of cancer because of embolism of pulmonary venous tumor into the middle cerebral artery, and a 21-year-old male osteosarcoma patient had a seizure-like attack after taking apatinib $750 \mathrm{mg}$ once daily for 3 days; the patient recovered gradually after stopping the drug. We had no explanation for this event

Table 3 Different disease and duration of response

\begin{tabular}{|c|c|c|c|c|}
\hline Pathological diagnosis & Target therapy protocol & Patients number (N) & Best response ${ }^{a}$ & $\begin{array}{l}\text { Median (average) } \\
\text { DR (months) }\end{array}$ \\
\hline Osteosarcoma & Apatinib alone & 22 & PR & $3.1(3.7)$ \\
\hline Ewing sarcoma & Apatinib + everolimus \& apatinib alone & 10 & PR & $1.5(3.3)$ \\
\hline Synovial sarcoma & Apatinib alone & 6 & PR & $5.2(5.8)$ \\
\hline MPNST $^{c}$ & Apatinib alone & 3 & PR & $8.8(10.1)$ \\
\hline Epithelioid sarcoma & Apatinib $+\mathrm{GT}^{\mathrm{b}}$ & 2 & PR & $(4.7)$ \\
\hline UPS $^{d}$ & Apatinib alone & 4 & PR & $5.6(5.0)$ \\
\hline Fibrosarcoma & Apatinib alone & 1 & PR & 2.7 \\
\hline Chondrosarcoma & Apatinib alone & 3 & PR & (7.4) \\
\hline ASPS $^{e}$ & Apatinib $+G T^{b}$ & 3 & $P R$ & $(7.4)$ \\
\hline Extraskeletal osteosarcoma & Apatinib alone & 1 & SD & 6.6 \\
\hline Mucinous type liposarcoma & Apatinib alone & 1 & PD & 1.0 \\
\hline
\end{tabular}

${ }^{\mathrm{a}} P R$ partial response, $S D$ stable disease according to RECIST 1.1

${ }^{b} G T$ chemo-protocol combined with gemcitabine $1000 \mathrm{mg} / \mathrm{m}^{2} \mathrm{~d}_{1,8}$ and docetaxel $75 \mathrm{mg} / \mathrm{m}^{2} \mathrm{~d}_{8}$

'MPNST malignant peripheral nerve sheath tumor

dUPS undifferentiated pleomorphic sarcoma

${ }^{\mathrm{e}}$ ASPS alveolar soft part sarcoma 


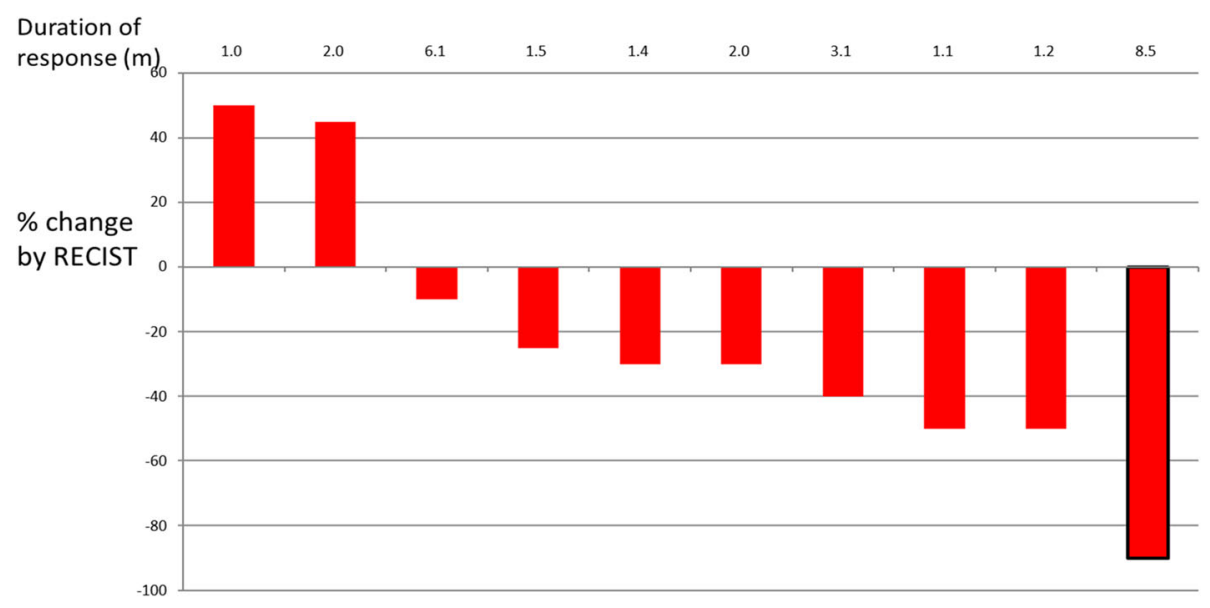

Fig. 2 Waterfall plot of best change from baseline for 10 Ewing sarcoma patients

except for a 3-week interval between stopping ifosfamide chemotherapy and starting apatinib; this rare scenario did not occur again in our series.

The adverse events are summarized in Table 4 . Twenty-six Grade 3 or 4 events were recorded. Although the daily dose of apatinib we used was lower than that used in the phase II of apatinib treatment of metastatic gastric cancer [12], adverse events were not fewer, although the main kinds of adverse events were slightly different: most Grade 3 and 4 toxicities were hypertension, pneumothorax, wound-healing problems, anorexia, and rash or desquamation.

\section{Discussion}

In this study, we found an objective response rate with apatinib used off-label in refractory relapsed sarcoma (40. 9\%(9/22) for osteosarcoma, 70\%(7/10) for Ewing's sarcoma, and 71.4\%(15/21) for soft tissue sarcoma). Also, except for osteosarcoma, the DR of other sarcomas was not inferior to that reported with other TKIs therapy, as shown in Table 5 [3, 4, 13-15]. In comparison with different combination of therapies, PFS seemed superior for apatinib together with sirolimus, but there was no statistically significant difference $(P=0.12)$. To determine apatinib's effectiveness, the drug should be evaluated separately in treatment of various types of tumors.

Osteosarcoma patients whose disease relapses after failing standard chemotherapy present a challenging treatment dilemma. Some patients, through aggressive surgical resection of all gross disease, may have longterm survival [16]. The choice of second-line chemotherapy and the use of investigational drugs are not standardized, and the outcomes are dismal [17]. Maldegem et al. [15] summarized phase I/II clinical trials conducted between 1990 and 2010 in osteosarcoma and Ewing's sarcoma; results were disappointing: only $8 \% \mathrm{CR}, 2.8 \%$ PR, and 4\% SD. Many active agents have been tested also in small series for treatment of osteosarcoma. Most

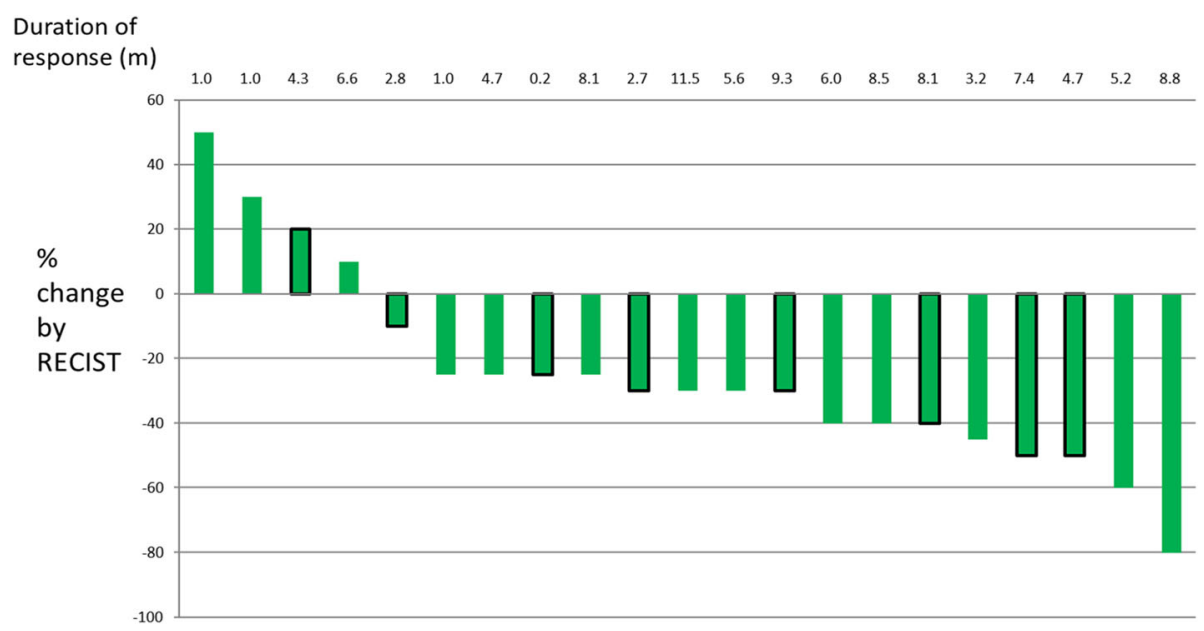

Fig. 3 Waterfall plot of best change from baseline for 21 soft tissue sarcoma patients 
Table 4 Adverse Events

\begin{tabular}{|c|c|c|c|c|}
\hline & Total N(\%) & Gra & & \\
\hline & & 1 & 2 & $3-4$ \\
\hline Apatinib alone ${ }^{a}$ & 45 (100\%) & & & \\
\hline Fatigue & $8(17.8 \%)$ & 5 & 2 & 1 \\
\hline Hypertension & $35(77.8 \%)$ & 27 & 3 & 5 \\
\hline Proteinuria & $4(8.9 \%)$ & 3 & 1 & \\
\hline Hand-foot syndrome & $12(26.7 \%)$ & 10 & 2 & \\
\hline Diarrhea & $9(20 \%)$ & 5 & 3 & 1 \\
\hline Weight loss & $19(42.2 \%)$ & 17 & 2 & \\
\hline Hair hypopigmentation & $25(55.6 \%)$ & 20 & 5 & \\
\hline Anorexia & $17(37.8 \%)$ & 10 & 4 & 3 \\
\hline Rash or desquamation & $26(57.8 \%)$ & 15 & 9 & 2 \\
\hline Mucositis & $2(4.4 \%)$ & 2 & & \\
\hline Pneumothorax & $9(20 \%)$ & & 3 & 6 \\
\hline Wound-healing problems & $6(13.3 \%)$ & & 1 & 5 \\
\hline Elevated Aminotransferase or bilirubin & $3(6.7 \%)$ & 2 & 1 & \\
\hline Thrombocytopenia & $7(15.6 \%)$ & 5 & 1 & 1 \\
\hline Seizure-like attack & $1(2.3 \%)$ & & & 1 \\
\hline Pancreatitis & $1(2.2 \%)$ & 1 & & \\
\hline Anemia & $2(4.4 \%)$ & 2 & & \\
\hline Cranial neuritis & $1(2.3 \%)$ & 1 & & \\
\hline Apatinib + everolimus ${ }^{b}$ & $7(100 \%)$ & & & \\
\hline Mucositis & $7(100 \%)$ & 2 & 4 & 1 \\
\hline Hypertension & $4(57.1 \%)$ & 2 & 2 & \\
\hline Rash or desquamation & $5(71.4 \%)$ & 2 & 3 & \\
\hline Gastrointestinal uncomfort & $1(14.3 \%)$ & & 1 & \\
\hline Apatinib $+G^{c}$ & $5(100 \%)$ & & & \\
\hline Hypertension & $1(20 \%)$ & & 1 & \\
\hline Rash or desquamation & $2(40 \%)$ & 2 & & \\
\hline Wound-healing problems & $1(20 \%)$ & 1 & & \\
\hline Thrombocytopenia & $2(40 \%)$ & 1 & 1 & \\
\hline
\end{tabular}

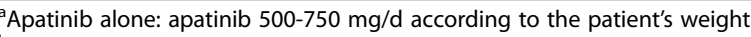

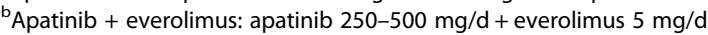
according to the patient's weight

${ }^{c} G T$ chemo-protocol combined with gemcitabine $1000 \mathrm{mg} / \mathrm{m}^{2} \mathrm{~d}_{1,8}$ and docetaxel $75 \mathrm{mg} / \mathrm{m}^{2} \mathrm{~d}_{8}$ once every 21 days

anti-angiogenesis TKIs can only keep the tumor stable but not make it shrink [18]. The greatest progress in phase II trials belongs to the Italian Sarcoma Group; they have held 2 cohort phase II trials with advanced osteosarcoma patients and found an objective response rate (ORR) of 14 and $10 \%$ [3, 4]. However, 45\% 6-month PFS (combination therapy) was less than the prespecified threshold of activity deemed worthy of a phase III trial (6-month PFS of $50 \%$ or greater). In Table 5, apatinib had a higher rate of response than did sorafenib, but the duration of response seemed to be shorter.
In this study, we did notice this phenomenon that sometimes most or some patients' lesions shrunk or remained stable during observation, while one or two lesions progressed. And this is especially common phenomenon happened during the third month after using apatinib for osteosarcoma. Patients might still get benefit from this VEGFR-2 highly selective drug with help of local therapy for those advanced lesion because of tumor heterogeneity. However as we use the criteria of RECIST 1.1, the duration of response seemed to be short. From our 56 patients, 4 osteosarcoma patients and one synovial sarcoma patient were in these circumstances.

Ewing's sarcoma is genetically characterized by chromosomal translocation involving the Ewing's sarcoma breakpoint region 1 (EWSR1) gene.. In this study we have 10 advanced Ewing's sarcoma cases. Table 5 illustrates that for refractory Ewing's sarcoma, the objective response rate was only 0 to $14.8 \%[15,19,20]$. Nevertheless, the DR for Ewing's sarcoma in various reports has been short compared with that of other sarcomas, with a median time of 5.7 weeks to less than 2 months [21-23]. In our study, more than half the Ewing's sarcoma patients took apatinib together with everolimus, whereas the remainder took apatinib alone. Seventy percent of all these patients, who had apatinib containing protocol, had partial response, which seemed to indicate that apatinib was the most effective in these trials, and that anti-VEGFR2 target therapy might be another promising approach for treating Ewing's sarcoma although with limited duration of response.

Soft tissue sarcoma is another huge group of sarcomas with diverse biological behaviors. For advanced cases, the only truly new treatment approved for sarcoma failing standard therapy is trabectedin, which has been approved by the European Medicines Agency 2007 [24]. Gemcitabine with dacarbazine or docetaxel [13, 25] and paclitaxel for treatment of angiosarcoma [26] seemed to improve PFS and OS in non-randomized and adaptively randomized trials. Targeted therapies, such as imatinib and sunitinib, have activity against gastrointestinal stromal tumors [27, 28]. Generally, anti-angiogenesis TKIs therapy with pazopanib has been a hallmark for all nonadipocytic soft tissue sarcoma after phase II and III trial verification, with median PFS 4.6 months (3.7-4.8 m; $95 \% \mathrm{CI}$ ) and best overall objective response rate of $6 \%$ $(14 / 246)$ [14, 29]. Thomas et al. [30] reported that regorafenib, which is an inhibitor of VEGFR-1, -2 and - 3 and tumor cell signaling kinases (RET, KIT, PDGFR, and Raf), yielded median PFS of 4.6 months in advanced sarcoma patients, which was almost the same as with pazopanib. Recently, the US Food and Drug Administration approved olaratumab [31], a human antiplatelet-derived growth factor receptor $\alpha$ monoclonal antibody, together with doxorubicin as first-line therapy for unresectable or 
Table 5 Previous studies about target therapy on sarcoma

\begin{tabular}{|c|c|c|c|c|c|c|}
\hline Drug & $\begin{array}{l}\text { Combined with } \\
\text { chemotherapy }\end{array}$ & $\begin{array}{l}\text { The first author's } \\
\text { last name }\end{array}$ & $\begin{array}{l}\text { Year of } \\
\text { publication }\end{array}$ & Trial Sponsor & $\begin{array}{l}\text { Number of } \\
\text { patients (N) }\end{array}$ & Clinical outcome \\
\hline \multicolumn{7}{|l|}{ osteosarcoma } \\
\hline & GT & Elizabeth Fox & 2012 & SARTCS ${ }^{f}$ & 14 & ORR 7.1\%; \\
\hline Sorafenib & no & Grignani & 2011 & $\begin{array}{l}\text { Italian Sarcoma } \\
\text { Group }\end{array}$ & 35 & $\begin{array}{l}4 \text { m-PFS }{ }^{\mathrm{a}} 46 \% ; \mathrm{DR}^{\mathrm{d}} 4 \mathrm{~m} ; \\
\mathrm{ORR}^{\mathrm{C}} 14 \% ;\end{array}$ \\
\hline Trastuzumab & $\begin{array}{l}\text { Cytotoxic } \\
\text { Chemotherapy }\end{array}$ & Ebb & 2012 & $\operatorname{COG}^{\mathrm{e}}$ & 41 & $\begin{array}{l}30 \text { m-EFS 32\%; } 30 \text { m-OS }{ }^{b} \\
50 \% \text {; without significant } \\
\text { difference comparing with } \\
\text { control group }\end{array}$ \\
\hline Sirolimus & Cyclophosphamide & Schuetze & 2012 & Michigan University & 5 & $\begin{array}{l}\text { ORR 0\%; } 4 \text { m-PFS 30\% } \\
\text { (combined with other } \\
\text { sarcoma) }\end{array}$ \\
\hline $\begin{array}{l}\text { Cixutumumab and } \\
\text { Temsirolimus }\end{array}$ & no & Schwartz & 2013 & MSKCC $^{g}$ fund & 24 & ORR 13\%; median PFS 6w \\
\hline Cixutumumab & no & Weigel & 2014 & COG & 11 & $\begin{array}{l}\text { ORR 0\%; 1/11 SD for } \\
140 \mathrm{~d}\end{array}$ \\
\hline R1507 & no & Pappo & 2014 & SARTCS & 38 & $\begin{array}{l}\text { ORR 2.5\%; DR: 12w; } \\
12 \text { w-PFS 17\% }\end{array}$ \\
\hline Sorafenib; Everolimus & no & Grignani & 2015 & Italian Sarcoma Group & 38 & $\begin{array}{l}6 \text { m-PFS 45\%; DR } 5 \text { m; } \\
\text { ORR 10\% }\end{array}$ \\
\hline $\begin{array}{l}\text { Cixutumumab; } \\
\text { Temsirolimus }\end{array}$ & no & Wagner & 2015 & COG & 11 & ORR 0\%; \\
\hline Dasatinib & no & Schuetze & 2016 & SARTCS & 46 & $\begin{array}{l}\text { ORR 6.5\%; DR } 5.7 \text { m; } \\
\text { 2y-OS 15\% }\end{array}$ \\
\hline Apatinib & no & Present study & 2017 & & 22 & $\begin{array}{l}\text { ORR 40.9\%;median PFS } \\
3.1 \\
\text { m; } 4 \text { m PFS 24.1\%; } 6 \text { m } \\
\text { PFS } 18.1 \%\end{array}$ \\
\hline \multicolumn{7}{|l|}{ Ewing sarcoma } \\
\hline & GT & Elizabeth Fox & 2012 & SARTCS & 14 & ORR 14.3\%; \\
\hline R1507 & no & Pappo & 2011 & SARTCS & 115 & $\begin{array}{l}\text { ORR 9.6\%; median PFS } \\
1.3 \\
\text { m; median OS } 7.6 \text { m }\end{array}$ \\
\hline Figitumumab & no & Juergens & 2011 & $\begin{array}{l}\text { European } \\
\text { organization }\end{array}$ & 106 & $\begin{array}{l}\text { ORR 14.2\%; median PFS } \\
1.9 \text { m; median OS } 8.9 \text { m }\end{array}$ \\
\hline $\begin{array}{l}\text { Cixutumumab }+ \\
\text { temsirolimus }\end{array}$ & no & Schwartz & 2013 & MSKCC & 27 & $\begin{array}{l}\text { ORR 14.8\%; median PFS } \\
7.5 \mathrm{w} \text {; median OS } 16.2 \mathrm{~m}\end{array}$ \\
\hline Olaparib & no & Choy E & 2014 & $M G H^{h}$ & 12 & ORR 0\%; DR 5.7w; \\
\hline $\begin{array}{l}\text { Cixutumumab + } \\
\text { temsirolimus }\end{array}$ & no & Wagner LM & 2015 & COG & 43 & ORR 0\%; $12 w-P F S$ 16\%; \\
\hline $\begin{array}{l}\text { Apatinib+everolimus \& } \\
\text { apatinib alone }\end{array}$ & no & Present study & 2017 & & 10 & $\begin{array}{l}\text { ORR } 70 \% \text {; median PFS } 2.0 \\
\text { m; } 12 \mathrm{w}-\mathrm{PFS} 22.5 \%\end{array}$ \\
\hline \multicolumn{7}{|l|}{ Soft tissue sarcoma } \\
\hline & $\begin{array}{l}\text { Topotecan } \\
\text { +carboplatin }\end{array}$ & Bochennek K & 2013 & CSTSG $^{\mathrm{i}}$ & 34 & ORR 38\%; \\
\hline Pazopanib & no & Winette T A & 2012 & $\begin{array}{l}\text { EORTC }^{j} \text { and the } \\
\text { PALETTE study group }\end{array}$ & 246 & $\begin{array}{l}\text { ORR 6\%; median PFS } 4.6 \\
\text { m; median OS } 12.5 \text { m }\end{array}$ \\
\hline Olaratumab & Doxorubicin & William D Tap & 2016 & $\begin{array}{l}\text { MSKCC and } 16 \text { clinical } \\
\text { sites in US }\end{array}$ & $\begin{array}{l}15 \text { in IB trial and } \\
67 \text { in II trial }\end{array}$ & $\begin{array}{l}\text { ORR 18.2\%; median PFS } \\
6.6 \text { m; median OS } 26.5 \text { m }\end{array}$ \\
\hline Regorafenib & no & $\begin{array}{l}\text { Thomas } \\
\text { Brodowicz }\end{array}$ & 2015 & $\begin{array}{l}\text { International trial } \\
\text { (France, Austria, } \\
\text { Germany) }\end{array}$ & 82 & $\begin{array}{l}\text { Median PFS } 5.6 \mathrm{~m} \text { for } \\
\text { SS and } 2.9 \mathrm{~m} \text { for none } \\
\text { specific; }\end{array}$ \\
\hline
\end{tabular}


Table 5 Previous studies about target therapy on sarcoma (Continued)

\begin{tabular}{|c|c|c|c|c|c|c|}
\hline Drug & $\begin{array}{l}\text { Combined with } \\
\text { chemotherapy }\end{array}$ & $\begin{array}{l}\text { The first author's } \\
\text { last name }\end{array}$ & $\begin{array}{l}\text { Year of } \\
\text { publication }\end{array}$ & Trial Sponsor & $\begin{array}{l}\text { Number of } \\
\text { patients (N) }\end{array}$ & Clinical outcome \\
\hline $\begin{array}{l}\text { Apatinib alone \& } \\
\text { apatinib+everolimus }\end{array}$ & $\begin{array}{l}\text { Sometimes } \\
\text { accompanied } \\
\text { with } \mathrm{GT}^{\mathrm{k}}\end{array}$ & Present study & 2017 & & 21 & $\begin{array}{l}\text { ORR } 71.4 \% ; \text { median PFS } \\
6.6 \text { m; } 4 \text { m-PFS } 71.4 \% ; \\
\text { median OS } 9.9 \text { m }\end{array}$ \\
\hline \multicolumn{7}{|l|}{ chondrosarcoma } \\
\hline & GT & Elizabeth Fox & 2012 & SARTCS & 25 & ORR 8\%; \\
\hline GDC-0449 & no & A. Italiano & 2013 & $\begin{array}{l}\text { French Sarcoma } \\
\text { Group/US; French } \\
\text { National Cancer } \\
\text { Institute }\end{array}$ & 39 & $\begin{array}{l}\text { ORR 0\%; median PFS } 3.5 \\
\text { m; 6-m PFS 28.2\%; } 1-y \\
\text { PFS 19.2\% }\end{array}$ \\
\hline Imatinib & no & Grignani & 2011 & Italian Sarcoma Group & 26 & $\begin{array}{l}\text { ORR 0\%; } 4 \text { m-PFS 31\%; } \\
\text { median OS } 11 \text { m; }\end{array}$ \\
\hline Sirolimus & cyclophosphamide & $\begin{array}{l}\text { Bernstein-Molho } \\
\text { R }\end{array}$ & 2012 & Israel & 10 & $\begin{array}{l}\text { ORR 10\%; } 60 \% \text { SD for } \\
\text { more than } 6 \text { m; median } \\
\text { PFS } 13.4 \text { m }\end{array}$ \\
\hline $\mathrm{IDH}^{\prime}$ inhibitor & no & $\begin{array}{l}\text { NCT02273739; } \\
\text { NCT02481154; } \\
\text { NCT02073994; } \\
\text { NCT02496741 }\end{array}$ & 2016-2017 & & & Under investigations \\
\hline Apatinib alone & no & Present study & 2017 & & 3 & $\begin{array}{l}\text { ORR 100\%; median } \\
\text { PFS } 7.37\end{array}$ \\
\hline
\end{tabular}

aPFS: progression-free survival

bOS: overall survival

'ORR: overall response rate, defined as complete responses (CRs) + partial responses (PRs) + MRs;

${ }^{\mathrm{d} D R}$ : Duration of response

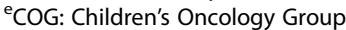

fSARTCS: Sarcoma Alliance for Research Through Collaboration Study

${ }^{9}$ MSKCC: Memorial Sloan-Kettering Cancer Center

hMGH: Massachusetts General Hospital

'CSTSG: Cooperative Soft Tissue Sarcoma Group

'EORTC: European Organization for Research and Treatment of Cancer

${ }^{k} \mathrm{GT}$ : chemo-protocol combined with gemcitabine $1000 \mathrm{mg} / \mathrm{m}^{2} \mathrm{~d}_{1,8}$ and docetaxel $75 \mathrm{mg} / \mathrm{m}^{2} \mathrm{~d}_{8}$

'IDH: isocitrate dehydrogenase

metastatic soft tissue sarcoma. The approval was based on the drug having significant improvement in median OS (11.8 months), however this is for initially treated soft tissue sarcoma not for refractory cases. We used various combinations of therapy, including apatinib, achieving ORR of $71.4 \%$, which is an astonishing result compared with other therapies [14, 24, 31] for treatment of advanced sarcoma. Although there were only 21 cases, we compared the subtype constitution in Table 3 and believed that it did not have obvious selective bias. In comparison with those agents, apatinib seemed to be more effective. The drug needs to be tested against other types of soft tissue sarcoma, such as MPNST and ASPS. We had 3 MPNST patients treated with apatinib, two of whom attained PR, and the PFS was 18.0 and 10 . 2 months. The other MPNST patient manifested as SD, and until last follow-up, at 4.3 months, her disease was stable. For target therapy for ASPS [29], objective response has rarely been reported, perhaps because the disease is indolent, progressing over decades, and few drugs have caused shrinkage of the tumors. However, with apatinib, which is a highly selective inhibitor of VEGFR-2, 2 of our 3 ASPS patients had PR, which seems a notable response. However, these PR cases firstly manifested as SD for 2 or 3 months and then started to shrink. However, the median OS with apatinib-containing therapy is shorter than that with pazopanib ( $9.9 \mathrm{~m}$ vs and $12.5 \mathrm{~m}$ ). We suppose that this difference may be because patients with secondary resistance to apatinib might quickly die of the disease without much more efficient treatment options.

Our experience with toxicity associated with apatinib (Table 4) seemed to be more severe from that described in clinical trials [7]. One patient had to stop using apatinib because of neuro-toxicity. Three patients had so serious anorexia and weight loss that they stopped using the agent. Nine of our patients had treatment-related pneumothorax and six patients had wound healing problems.

We acknowledge this study's limitations. First, it is a retrospective study that some patients might have some combination therapy which made this study not so suitable for comparion with other drugs. Second, because of the rarity of some types of sarcoma, we had insufficient numbers to permit subset analyses, which could have reduced the statistical power. Third, the study is off-label; hence, it may not have been as rigorously controlled as 
are prospective trials. Finally, 5 patients were lost to follow-up, which may have affected data accuracy.

\section{Conclusions}

Apatinib might be with a high objective response rate, in an off-label study of sarcoma patients who had tumors not amenable to curative treatment or inclusion in clinical trials. The duration of response were consistent with responses reported in clinical trials with other antiangiogenesis TKIs. Investigation of apatinib in the treatment of some special subtypes of sarcoma, for example metastatic MPNST and ASPS, in prospective trials is needed.

\begin{abstract}
Abbreviations
95\% Cl: 95\% confidence interval; AEs: Adverse events; ASPS: Alveolar soft part sarcoma; BSA: Body surface area; CS: Chondrosarcomas; DR: Duration of response; EFS: Event-free survival; ES: Ewing's sarcoma; ESFT: Ewing's sarcoma family tumors; GT: Gemcitabine and docetaxel; IDH: Isocitrate dehydrogenase; IGF-1R: Insulin-like growth factor 1 receptor; MPNST: Malignant peripheral nerve sheath tumors; mTOR: Mammalian target of rapamycin; ORR: Object response rate; OS: Overall survival; PDGFR: Plateletderived growth factor receptor; PFS: Progression-free survival; PR: Partial response; RECIST: Response Evaluation Criteria for Solid Tumors; SD: Stable disease; STS: Soft tissue sarcomas; TKIs: Tyrosine Kinase Inhibitors; UPS: Undifferentiated pleomorphic sarcoma; VDC-IE: Vincristine, doxorubicin, cyclophosphamide sequenced with ifosfamide, etoposide; VEGFR: Vascula endothelial growth factor receptor; VTI: Vincristine, temozolomide, irinotecan
\end{abstract}

\section{Acknowledgements}

We thank Dr. Shen Danhua and Dr. Sun Kunkun for reviewing all the pathological slides of these sarcoma patients and Dr. Li Yuan for doing clinical PET/CT evaluation for all our patients.

\section{Funding}

One of the authors (TJ) has received research support funding from the National Natural Science Foundation of China (No. 81402382). The funding body had no role in the design of the study and collection, analysis, and interpretation of data and in writing the manuscript.

\section{Availability of data and materials \\ The data that support the findings of this study are available from the patients' database of Peking University People's Hospital, Peking University Shougang Hospital and Peking University International Hospital separately but restrictions apply to the availability of these data, which were used under license for the current study, and so are not publicly available. Data are however available from the corresponding author upon reasonable request and with permission of Peking University People's Hospital, Peking University Shougang Hospital and Peking University International Hospital.}

\section{Authors' contributions}

WG, YW and TY designed and developed this retrospective study. LX and JX collected all the patients' basic information. LX analyzed and interpreted patients' data and was a major contributor in writing the manuscript. TJ did statistical analysis and revised the article separately. All authors read and approved the final manuscript.

\section{Ethics approval and consent to participate}

This study was approved by the institutional review board, Peking University People's Hospital, Peking University Shougang Hospital and Peking University International Hospital Ethics Committee for Clinical Investigation. All those patients had signed informed consent forms for data collection and use for research purpose, of which children patients' informed forms had be signed by their legal parents. The ethical approval reference number was IRBK-2017-019-01.

\section{Consent for publication}

All those patients had signed informed consent forms for data collection and publication, of which children patients' informed forms had been signed by their legal parents.

\section{Competing interests}

The authors declare that they have no competing interests in this article.

\section{Publisher's Note}

Springer Nature remains neutral with regard to jurisdictional claims in published maps and institutional affiliations.

\section{Author details}

${ }^{1}$ Peking University People's Hospital, Peking, China. ${ }^{2}$ Peking University Shougang Hospital, Peking, China. ${ }^{3}$ Peking University International Hospital, Peking, China.

Received: 6 September 2017 Accepted: 26 March 2018

Published online: 06 April 2018

\section{References}

1. Paulussen M, Bielack S, Jurgens H, Casali PG, Group EGW. Ewing's sarcoma of the bone: ESMO clinical recommendations for diagnosis, treatment and follow-up. Ann Oncol. 2009:20(Suppl 4):140-2.

2. Jo WY, Doyle LA. Refinements in sarcoma classification in the current 2013 World Health Organization classification of Tumours of soft tissue and bone. Surg Oncol Clin N Am. 2016;25(4):621-43.

3. Grignani G, Palmerini E, Dileo P, Asaftei SD, D'Ambrosio L, Pignochino Y, Mercuri M, Picci P, Fagioli F, Casali PG, et al. A phase II trial of sorafenib in relapsed and unresectable high-grade osteosarcoma after failure of standard multimodal therapy: an Italian sarcoma group study. Ann Oncol. 2012;23(2):508-16

4. Grignani G, Palmerini E, Ferraresi V, D'Ambrosio L, Bertulli R, Asaftei SD, Tamburini A, Pignochino Y, Sangiolo D, Marchesi E, et al. Sorafenib and everolimus for patients with unresectable high-grade osteosarcoma progressing after standard treatment: a non-randomised phase 2 clinical trial. Lancet Oncol. 2015;16(1):98-107.

5. van der Graaf WT, Blay JY, Chawla SP, Kim DW, Bui-Nguyen B, Casali PG, Schoffski P, Aglietta M, Staddon AP, Beppu Y, et al. Pazopanib for metastatic soft-tissue sarcoma (PALETTE): a randomised, double-blind, placebo-controlled phase 3 trial. Lancet. 2012;379(9829):1879-86.

6. Li J, Qin S, Xu J, Xiong J, Wu C, Bai Y, Liu W, Tong J, Liu Y, Xu R, et al. Randomized, double-blind, placebo-controlled phase III trial of Apatinib in patients with chemotherapy-refractory advanced or metastatic adenocarcinoma of the stomach or gastroesophageal junction. J Clin Oncol. 2016:34(13):1448-54

7. Li J, Qin S, Xu J, Guo W, Xiong J, Bai Y, Sun G, Yang Y, Wang L, Xu N, et al. Apatinib for chemotherapy-refractory advanced metastatic gastric cancer: results from a randomized, placebo-controlled, parallel-arm, phase II trial. J Clin Oncol. 2013:31(26):3219-25.

8. Ding Q, Cheng X, Yang L, Zhang Q, Chen J, Li T, Shi H. PET/CT evaluation of response to chemotherapy in non-small cell lung cancer: PET response criteria in solid tumors (PERCIST) versus response evaluation criteria in solid tumors (RECIST). J Thorac Dis. 2014;6(6):677-83.

9. Verger $\mathrm{E}$, Salamero M, Conill C. Can Karnofsky performance status be transformed to the eastern cooperative oncology group scoring scale and vice versa? Eur J Cancer. 1992:28A(8-9):1328-30

10. Li J, Zhao X, Chen L, Guo H, Lv F, Jia K, Yv K, Wang F, Li C, Qian J, et al. Safety and pharmacokinetics of novel selective vascular endothelial growth factor receptor-2 inhibitor YN968D1 in patients with advanced malignancies. BMC Cancer. 2010;10:529.

11. Cirillo M, Venturini M, Ciccarelli L, Coati F, Bortolami O, Verlato G. Clinician versus nurse symptom reporting using the National Cancer Institutecommon terminology criteria for adverse events during chemotherapy: results of a comparison based on patient's self-reported questionnaire. Ann Oncol. 2009:20(12):1929-35.

12. Fornaro L, Vasile E, Falcone A. Apatinib in advanced gastric Cancer: a doubtful step forward. J Clin Oncol. 2016;34(31):3822-3823. https://doi.org/10.1200/JCO. 2016.68.6931.

13. Fox E, Patel S, Wathen JK, Schuetze S, Chawla S, Harmon D, Reinke D, Chugh R, Benjamin RS, Helman LJ. Phase II study of sequential gemcitabine 
followed by docetaxel for recurrent Ewing sarcoma, osteosarcoma, or unresectable or locally recurrent chondrosarcoma: results of sarcoma alliance for research through collaboration study 003. Oncologist. 2012;17(3): 321.

14. Sleijfer S, Ray-Coquard I, Papai Z, Le Cesne A, Scurr M, Schoffski P, Collin F, Pandite L, Marreaud S, De Brauwer A, et al. Pazopanib, a multikinase angiogenesis inhibitor, in patients with relapsed or refractory advanced soft tissue sarcoma: a phase II study from the European organisation for research and treatment of cancer-soft tissue and bone sarcoma group (EORTC study 62043). J Clin Oncol. 2009;27(19):3126-32.

15. van Maldegem AM, Bhosale A, Gelderblom HJ, Hogendoorn PC, Hassan AB. Comprehensive analysis of published phase I/II clinical trials between 19902010 in osteosarcoma and Ewing sarcoma confirms limited outcomes and need for translational investment. Clin Sarcoma Res. 2012;2(1):5.

16. Kempf-Bielack B, Bielack SS, Jurgens H, Branscheid D, Berdel WE, Exner GU, Gobel U, Helmke K, Jundt G, Kabisch H, et al. Osteosarcoma relapse after combined modality therapy: an analysis of unselected patients in the cooperative osteosarcoma study group (COSS). J Clin Oncol. 2005;23(3):559-68.

17. Lagmay JP, Krailo MD, Dang H, Kim A, Hawkins DS, Beaty O 3rd, Widemann BC, Zwerdling T, Bomgaars L, Langevin AM, et al. Outcome of patients with recurrent osteosarcoma enrolled in seven phase II trials through Children's Cancer group, pediatric oncology group, and Children's oncology group: learning from the past to move forward. J Clin Oncol. 2016;34(25):3031-8.

18. Fox E, Aplenc R, Bagatell R, Chuk MK, Dombi E, Goodspeed W, Goodwin A, Kromplewski M, Jayaprakash N, Marotti M, et al. A phase 1 trial and pharmacokinetic study of cediranib, an orally bioavailable pan-vascular endothelial growth factor receptor inhibitor, in children and adolescents with refractory solid tumors. J Clin Oncol. 2010;28(35):5174-81.

19. Cotterill SJ, Ahrens S, Paulussen M, Jurgens HF, Voute PA, Gadner H, Craft AW. Prognostic factors in Ewing's tumor of bone: analysis of 975 patients from the European intergroup cooperative Ewing's sarcoma study group. J Clin Oncol. 2000;18(17):3108-14.

20. Esiashvili N, Goodman M, Marcus RB Jr. Changes in incidence and survival of Ewing sarcoma patients over the past 3 decades: surveillance epidemiology and end results data. J Pediatr Hematol Oncol. 2008;30(6): 425-30.

21. Rowinsky EK, Youssoufian H, Tonra JR, Solomon P, Burtrum D, Ludwig DL. IMC-A12, a human IgG1 monoclonal antibody to the insulin-like growth factor I receptor. Clin Cancer Res. 2007;13(18 Pt 2):5549s-55s.

22. Naing A, LoRusso P, Fu S, Hong DS, Anderson P, Benjamin RS, Ludwig J, Chen HX, Doyle LA, Kurzrock R. Insulin growth factor-receptor (IGF-1R) antibody cixutumumab combined with the mTOR inhibitor temsirolimus in patients with refractory Ewing's sarcoma family tumors. Clin Cancer Res. 2012;18(9):2625-31.

23. Pappo AS, Vassal G, Crowley JJ, Bolejack V, Hogendoorn PC, Chugh R, Ladanyi M, Grippo JF, Dall G, Staddon AP, et al. A phase 2 trial of R1507, a monoclonal antibody to the insulin-like growth factor-1 receptor (IGF-1R), in patients with recurrent or refractory rhabdomyosarcoma, osteosarcoma, synovial sarcoma, and other soft tissue sarcomas: results of a sarcoma alliance for research through collaboration study. Cancer. 2014;120(16): 2448-56.

24. Martin-Broto J, Pousa AL, de Las Penas R, Garcia Del Muro X, Gutierrez A, Martinez-Trufero J, Cruz J, Alvarez R, Cubedo R, Redondo A, et al. Randomized phase II study of Trabectedin and doxorubicin compared with doxorubicin alone as first-line treatment in patients with advanced soft tissue sarcomas: a Spanish Group for Research on sarcoma study. J Clin Oncol. 2016;34(19):2294-302.

25. Garcia-Del-Muro X, Lopez-Pousa A, Maurel J, Martin J, Martinez-Trufero J, Casado A, Gomez-Espana A, Fra J, Cruz J, Poveda A, et al. Randomized phase II study comparing gemcitabine plus dacarbazine versus dacarbazine alone in patients with previously treated soft tissue sarcoma: a Spanish Group for Research on sarcomas study. J Clin Oncol. 2011;29(18):2528-33.

26. Penel N, Bui BN, Bay JO, Cupissol D, Ray-Coquard I, Piperno-Neumann S, Kerbrat P, Fournier C, Taieb S, Jimenez M, et al. Phase II trial of weekly paclitaxel for unresectable angiosarcoma: the ANGIOTAX study. J Clin Oncol. 2008;26(32):5269-74.

27. Fu Y, Kang H, Zhao H, Hu J, Zhang H, Li X, Du N, Huang Y. Sunitinib for patients with locally advanced or distantly metastatic dermatofibrosarcoma protuberans but resistant to imatinib. Int J Clin Exp Med. 2015;8(5):8288-94.

28. Patrikidou A, Domont J, Chabaud S, Ray-Coquard I, Coindre JM, Bui-Nguyen B, Adenis A, Rios M, Bertucci F, Duffaud F, et al. Long-term outcome of molecular subgroups of GIST patients treated with standard-dose imatinib in the BFR14 trial of the French sarcoma group. Eur J Cancer. 2016;52:173-80.

29. Bains R, Magdum A, Bhat W, Roy A, Platt A, Stanley P. Soft tissue sarcoma a review of presentation, management and outcomes in 110 patients. Surgeon. 2016;14(3):129-35.

30. Brodowicz T, Liegl-Atzwager B, Tresch E, Taieb S, Kramar A, Gruenwald V, Vanseymortier M, Clisant S, Blay JY, Le Cesne A, et al. Study protocol of REGOSARC trial: activity and safety of regorafenib in advanced soft tissue sarcoma: a multinational, randomized, placebo-controlled, phase II trial. BMC Cancer. 2015;15:127.

31. Tap WD, Jones RL, Van Tine BA, Chmielowski B, Elias AD, Adkins D, Agulnik $M$, Cooney MM, Livingston MB, Pennock $G$, et al. Olaratumab and doxorubicin versus doxorubicin alone for treatment of soft-tissue sarcoma: an open-label phase $1 \mathrm{~b}$ and randomised phase 2 trial. Lancet. 2016; 388(10043):488-97.

\section{Submit your next manuscript to BioMed Central and we will help you at every step:}

- We accept pre-submission inquiries

- Our selector tool helps you to find the most relevant journal

- We provide round the clock customer support

- Convenient online submission

- Thorough peer review

- Inclusion in PubMed and all major indexing services

- Maximum visibility for your research

Submit your manuscript at www.biomedcentral.com/submit
C Biomed Central 